\title{
Stability Analysis of a High Fibre Yield and Low Lignin Content "Thick Stem" Mutant in Tossa Jute (Corchorus olitorius L.)
}

\author{
Aninda Mandal and Animesh K. Datta \\ Department of Botany, Cytogenetics, Genetics and Plant Breeding Section, Kalyani University, Kalyani, West Bengal 741235, India
}

Correspondence should be addressed to Animesh K. Datta; dattaanimesh@gmail.com

Received 14 February 2014; Accepted 7 April 2014; Published 22 April 2014

Academic Editor: Andrei Surguchov

Copyright (C) 2014 A. Mandal and A. K. Datta. This is an open access article distributed under the Creative Commons Attribution License, which permits unrestricted use, distribution, and reproduction in any medium, provided the original work is properly cited.

\begin{abstract}
A "thick stem" mutant of Corchorus olitorius $\mathrm{L}$. was induced at $\mathrm{M}_{2}(0.50 \%, 4 \mathrm{~h}, \mathrm{EMS})$ and the true breeding mutant is assessed across generations $\left(M_{5}\right.$ to $\left.M_{7}\right)$ considering morphometric traits as well as SEM analysis of pollen grains and raw jute fibres, stem anatomy, cytogenetical attributes, and lignin content in relation to control. Furthermore, single fibre diameter and tensile strength are also analysed. The objective is to assess the stability of mutant for its effective exploration for raising a new plant type in tossa jute for commercial exploitation and efficient breeding. The mutant trait is monogenic recessive to normal. Results indicate that "thick stem" mutant is stable across generations $(2 n=14)$ with distinctive high seed and fibre yield and significantly low lignin content. Stem anatomy of the mutant shows significant enhancement in fibre zone, number of fibre pyramids and fibre bundles per pyramid, and diameter of fibre cell in relation to control. Moreover, tensile strength of mutant fibre is significantly higher than control fibre and the trait is inversely related to fibre diameter. However the mutant is associated with low germination frequency, poor seed viability, and high pollen sterility, which may be eliminated through mutational approach followed by rigorous selection and efficient breeding.
\end{abstract}

\section{Introduction}

Induction of mutation forms an integral part of breeding program as it widens the gene pool through creation of genetic variability. The methodology has been successfully adapted for crop improvement and release of elite "plant type" mutants [1] including Corchorus olitorius (tossa jute; family: Tiliaceae), an important fibre yielding crop of commerce [2-5]. A "thick stem" (designated as "thick stem I") mutant was isolated from $\mathrm{M}_{2}$ mutagenised population of C. olitorius var. JRO 524 following seed treatment with ethyl methane sulphonate (EMS) and the mutant bred true at $\mathrm{M}_{4}$ generation [6]. Present investigation describes the "thick stem" mutant in relation to control considering morphometric traits as well as scanning electron microscopic (SEM) analysis of pollen grains and raw jute fibres, anatomical (stem anatomy) attributes, cytogenetical (meiosis and inheritance of the mutant trait) parameters, and biochemical (lignin and holocellulose contents) aspects in advanced generations $\left(\mathrm{M}_{5}\right.$ to $\mathrm{M}_{7}$ ) under uniform environmental conditions. Furthermore, single fibre diameter and tensile strength are also analysed. The objective of the work is to assess the stability of the mutant across generations for its effective exploration in raising a new "plant type" as well as in efficient breeding in tossa jute.

\section{Materials and Methods}

2.1. Germplasms. Selfed seeds of true breeding $\mathrm{M}_{4}$ "thick stem" mutant (raised at $\mathrm{M}_{2}$ following $0.50 \%, 4 \mathrm{~h}$ EMS treatment) as well as selfed control lines (seeds of 5 phenotypically stable plants in each case were considered in each generation) of C. olitorius L. var. JRO 524 (mother seed stock obtained from Central Research Institute for Jute and Allied Fibres, West Bengal, India, in the year 2006) were sown in randomised block design with 3 replications (plot size: $3 \mathrm{~m} \times$ $1.5 \mathrm{~m}$; between plants $30 \mathrm{~cm}$ and rows $20 \mathrm{~cm}$ ). Plants were grown in experimental field plots of Kalyani University (West Bengal plain, Nadia: latitude $22^{\circ} 50^{\prime}$ to $24^{\circ} 11^{\prime} \mathrm{N}$, longitude $88^{\circ} 09^{\prime}$ to $88^{\circ} 48^{\prime} \mathrm{E}$, altitude $9.75 \mathrm{~m}$; sandy loamy soil, soil $\mathrm{pH}$ 
6.85) from March to October 2010, 2011, and $2012\left(M_{5}\right.$ to $\left.M_{7}\right)$. No fertilizer application was made during the growth period of the plant types.

2.2. Study of Quantitative Parameters. Germination frequency (Petri plates as well as field; data for field is pooled over the plots) and morphometric traits assessed are presented in Table 1 . On an average 15 to 20 randomly selected plants were studied for quantitative parameters in each plant type, in each generation. Quantitative parameters were studied on harvest. Fibre yield in the plant types was estimated following the conventional method of whole plant retting. For the purpose, defoliated plants of mutant and control were dipped in stagnant water in a cistern (artificially prepared). Brick bats tied in cement bags were used to deep the jak materials. Retting was completed within 15 to 20 days. Fibres were extracted by "beat-break-jerk" method. The fibres extracted from a single plant were sun-dried before weighing.

Seed viability was tested using $1 \%$ tetrazolium chloride following the method suggested by Patil and Dadlani [7].

2.3. Girth of Stem and Anatomical Attributes. Girth of stem was assessed in both the plant types uniformly from base, middle, and upper zones. Stem anatomical features (Table 3) of "thick stem" mutant (assessed at $\mathrm{M}_{7}$ ) in relation to control were analysed from suitable transverse sections from base, middle, and upper portions. The sections were stained following the method described by Johansen [8]. Photomicrographs were taken from suitable sections.

2.4. Meiotic Analyses. For the meiotic studies, 3 to 5 floral buds of suitable size from 3 randomly selected plants of both plant types were fixed ( $6 \mathrm{am}$ to $7 \mathrm{am})$ in each generation $\left(\mathrm{M}_{5}\right.$ to $\left.\mathrm{M}_{7}\right)$ in Carnoy's fixative (6 ethanol:3 chloroform:1 acetic acid). Two changes at an interval of $24 \mathrm{~h}$ were given in the fixative and preserved in $70 \%$ alcohol under refrigerated condition. Pollen mother cells (PMCs) and pollen grains obtained from anther squash preparations were stained in $2 \%$ propinocarmine solution. Fully stained pollen grains were considered fertile [9]. Data were scored from scattered diplotene-diakinesis, metaphase I (MI), and anaphase I (AI) meiocytes and pooled over the buds in each plant type. Photomicrographs were taken from temporary slide preparation and subsequently magnified.

2.5. Study of Inheritance Pattern. At anthesis ( $9 \mathrm{am}$ to $11 \mathrm{am}$ ) reciprocal crossings between control and "thick stem" mutant (20 crosses in each set) were performed considering all necessary precautionary measures to avoid genetic contaminations as well as autogamy. Hybrid seeds obtained were sown to raise $\mathrm{F}_{1}$ plant population. The $\mathrm{F}_{1}$ plants were selfed (5 floral buds were bagged at the onset of anthesis in each category) and seeds obtained were sown to raise $\mathrm{F}_{2}$ plants. The $\mathrm{F}_{2}$ plants segregated into normal and mutant phenotypes and $\chi^{2}$ test analysis was performed to assess segregation pattern.

2.6. SEM Analyses. Surface morphology of pollen grains (matured pollen grains from fully opened flowers) and raw jute fibres of control and mutant was studied under SEM (Zeiss EVO HD, Oberkochen, Germany) at $15 \mathrm{kV}$ accelerating voltage at GSI (Geological Survey of India, Kolkata, West Bengal, India). Photomicrographs were taken from suitable preparations. Pollen shape and size were determined as per Erdtman [10].

2.7. Biochemical Analyses. Lignin content was analysed in control and in "thick stem" mutant (5 plants of each plant type were considered) from retted fibres of harvested $\mathrm{M}_{7}$ plants as per Sengupta et al. [11]. For the purpose, dry milled fibres were thoroughly cleaned of wax and oil in a Soxhlet apparatus using a mixture of benzene and ethanol $(2: 1 \mathrm{v} / \mathrm{v})$ and dried under vacuum. The samples ( $5 \mathrm{~g}$ in each case) were treated with $0.7 \%$ sodium chloride solution at $\mathrm{pH} 4.0$, maintained by acetic acid for $2 \mathrm{~h}$ in a boiling water bath. The process was repeated 3 times and the samples were brought to neutral $\mathrm{pH}$ by washing with $2 \%$ sodium metabisulphite and water at $60^{\circ} \mathrm{C}$, cooled and dried in desiccators to a constant weight to get the amount of holocellulose. The lignin content was determined by subtracting the amount of holocellulose from that of the dewaxed samples.

2.8. Diameter of Fibre. Fibres extracted from untreated control and mutant $\left(\mathrm{M}_{7}\right.$ harvested plants) plant types were polygonal in shape and nonuniform in thickness. The fibres were considered as perfectly cylindrical to simplify measurements in accordance to de Rosa et al. [12]. Each fibre was manually separated from both plant types and measured in a light microscope at 10x magnification and diameter was calculated. Randomly 25 fibres from each set (control and mutant) were analysed. Uniformly $60 \mathrm{~mm}$ stretch of each fibre was tested. For each fibre, an average of 3 measurements (mean represented) of diameter at 3 different regions were taken as the diameter of that fibre.

2.9. Tensile Strength. Fibre strength was determined from the machine "Fibre bundle strength tester" following the methodology adopted by Bandyopadhyay and Mukhopadhyay [13]. The formula used to calculate Fibre bundle strength, which is (Breaking load in kilogram $\times$ length of bundle in $\mathrm{cm} \times 10$ )/Sample weight in milligram, is expressed in $\mathrm{g} / \mathrm{tex}$. For the purpose, 10 bundles from each plant type were assessed.

2.10. Statistical Analyses. Student $t$-test was performed between control and mutant to assess significant variations, if any, considering morphometric traits (pooled over the generations) and anatomical attributes. Furthermore, $\chi^{2}$ test of heterogeneity was conducted for each quantitative parameter to ascertain stability across the generations.

\section{Results}

Seed germination frequency across the generation was noted to be $84.0 \%$ to $86.0 \%$ and $68.0 \%$ to $72.0 \%$ in control and $28.0 \%$ to $32.0 \%$ and $18.0 \%$ to $20.0 \%$ in "thick stem" mutant under Petri plate and field conditions, respectively. Percentage of 


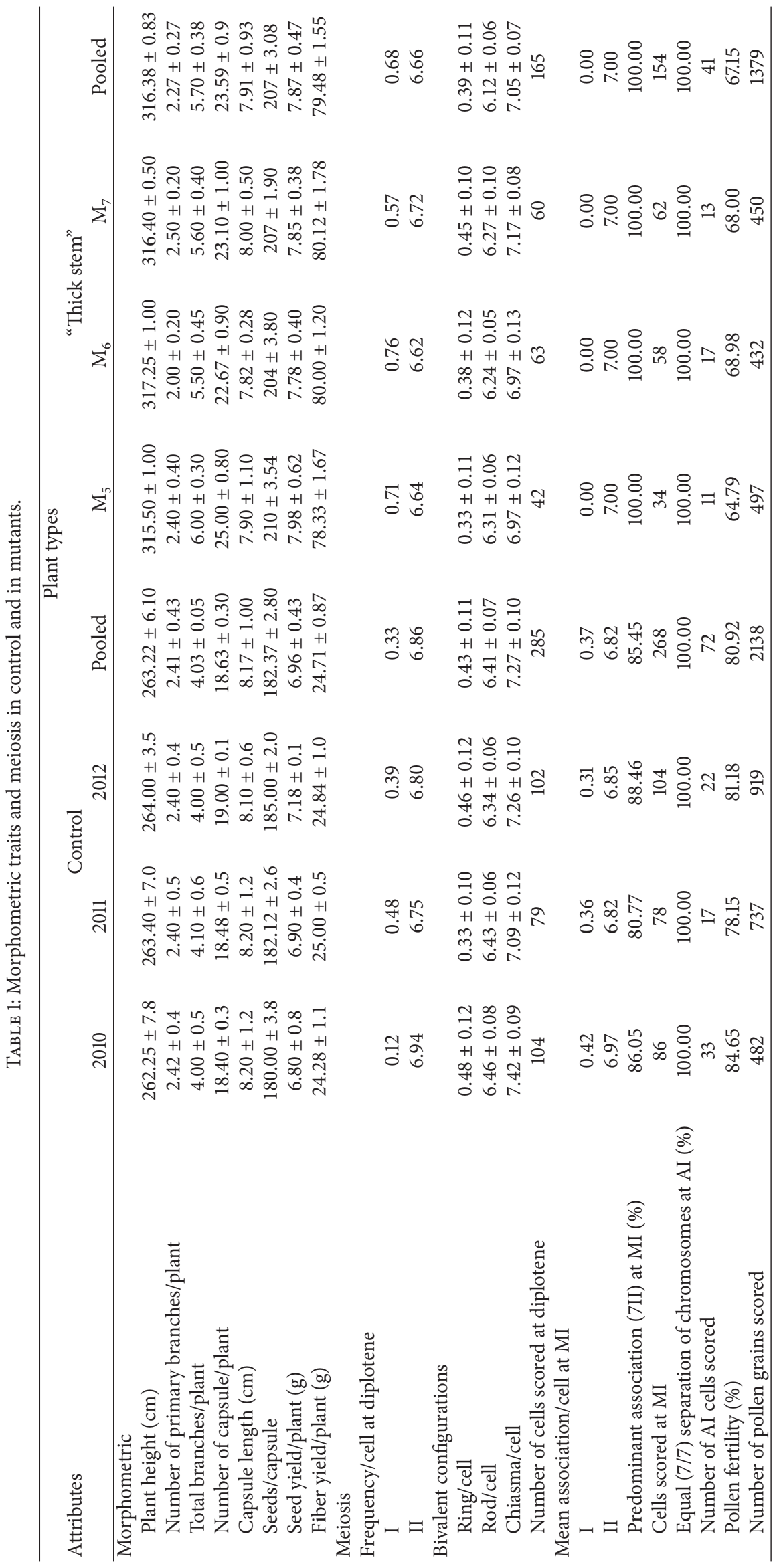


TABLE 2: Girth of the stem in the plant types.

\begin{tabular}{|c|c|c|c|c|c|c|c|c|c|c|}
\hline \multirow{3}{*}{ Attributes } & \multicolumn{8}{|c|}{ Plant types } & \multirow{3}{*}{$\begin{array}{l}t \text { value } \\
\text { at } 8 \mathrm{DF}\end{array}$} & \multirow{3}{*}{$P$ value } \\
\hline & \multicolumn{4}{|c|}{ Control } & \multicolumn{4}{|c|}{ “Thick stem" } & & \\
\hline & 2010 & 2011 & 2012 & Pooled & $\mathrm{M}_{5}$ & $\mathrm{M}_{6}$ & $\mathrm{M}_{7}$ & Pooled & & \\
\hline \multicolumn{11}{|c|}{ Girth of stem $(\mathrm{cm})$} \\
\hline Basal & $7.62 \pm 0.47$ & $7.87 \pm 0.45$ & $7.81 \pm 0.20$ & $7.77 \pm 0.37$ & $14.10 \pm 0.37$ & $13.90 \pm 0.51$ & $13.55 \pm 0.48$ & $13.85 \pm 0.20$ & 23.27 & $<0.001$ \\
\hline Middle & $5.77 \pm 0.85$ & $5.85 \pm 0.70$ & $5.72 \pm 0.24$ & $5.78 \pm 0.60$ & $12.20 \pm 0.21$ & $11.92 \pm 0.45$ & $12.10 \pm 0.37$ & $12.07 \pm 0.34$ & 24.49 & $<0.001$ \\
\hline Upper & $4.00 \pm 0.43$ & $3.47 \pm 0.14$ & $4.00 \pm 0.37$ & $3.82 \pm 0.31$ & $7.80 \pm 0.37$ & $7.60 \pm 0.30$ & $8.00 \pm 0.37$ & $7.80 \pm 0.35$ & 9.53 & $<0.001$ \\
\hline
\end{tabular}

TABLE 3: Stem anatomical attributes in the plant types of C. olitorius.

\begin{tabular}{|c|c|c|c|c|c|}
\hline \multirow{2}{*}{ Attributes } & \multirow{2}{*}{ Zones } & \multicolumn{2}{|c|}{ Genotypes } & \multirow{2}{*}{$t$ value at $8 \mathrm{DF}$} & \multirow{2}{*}{$P$ value } \\
\hline & & Control & "Thick stem" & & \\
\hline \multirow{3}{*}{ Fibre zone $\left(\mathrm{cm}^{2}\right)$} & Base & $0.53 \pm 0.01$ & $4.02 \pm 0.09$ & 16.43 & $<0.001$ \\
\hline & Middle & $0.30 \pm 0.01$ & $3.12 \pm 0.07$ & 11.87 & $<0.001$ \\
\hline & Upper & $0.21 \pm 0.01$ & $1.20 \pm 0.05$ & 21.50 & $<0.001$ \\
\hline \multirow{3}{*}{ Number of fibre pyramid per T.S. } & Base & $60.20 \pm 1.16$ & $96.40 \pm 0.51$ & 28.60 & $<0.001$ \\
\hline & Middle & $50.80 \pm 0.86$ & $87.00 \pm 0.71$ & 32.50 & $<0.001$ \\
\hline & Upper & $45.20 \pm 1.16$ & $70.00 \pm 0.71$ & 18.30 & $<0.001$ \\
\hline \multirow{3}{*}{ Number of fibre bundle per pyramid } & Base & $41.80 \pm 1.43$ & $75.40 \pm 1.44$ & 16.60 & $<0.001$ \\
\hline & Middle & $26.80 \pm 0.80$ & $57.80 \pm 0.49$ & 33.00 & $<0.001$ \\
\hline & Upper & $16.00 \pm 0.32$ & $31.00 \pm 0.32$ & 33.50 & $<0.001$ \\
\hline \multirow{3}{*}{ Diameter of fibre cell $(\mu \mathrm{m})$} & Base & $15.60 \pm 0.25$ & $18.60 \pm 0.37$ & 7.16 & $<0.001$ \\
\hline & Middle & $16.00 \pm 0.32$ & $18.80 \pm 0.37$ & 5.72 & $<0.001$ \\
\hline & Upper & $18.00 \pm 0.32$ & $21.20 \pm 0.37$ & 6.53 & $<0.001$ \\
\hline
\end{tabular}

seed viability was also found to be much lower in mutant (10.0\% to $15.0 \%)$ than control $(96.0 \%$ to $98.0 \%)$.

3.1. Analyses of Quantitative Parameters. Data analysed for morphometric traits of control (Figure 1(a)) and "thick stem" mutant (Figure 1(b)) across the generation are presented in Table 1. Results indicated that "thick stem" mutant in relation to control shows significant $(P<0.01$ to 0.001$)$ enhancement of plant height, total number of branches per plant, total capsules per plant, seeds per capsule, seed yield per plant, and fibre yield per plant. Fibre yield per plant was convincingly higher in the mutant $(78.33 \mathrm{~g} \pm 1.67$ to $80.12 \mathrm{~g} \pm 1.78)$ than control $(24.28 \mathrm{~g} \pm 1.10$ to $25.00 \mathrm{~g} \pm 0.50)$. The quantitative traits were found to be randomly distributed $(P>0.05, \mathrm{DF}$ 2 ) across the generations in both plant types.

3.2. Girth of the Stem and Anatomical Features. Anatomical attributes of control and mutant plant types are presented in Tables 2 and 3. Girth of stem of mutant was significantly thicker in base, middle, and upper zone than control (Table 2, Figure 1(c)). Study of transverse sections of stem of the mutant from base, middle, and upper portions revealed significant $(P<0.001)$ enhancement in fibre zone, number of fibre pyramids per section, number of fibre bundles per pyramid, and diameter of fibre cell in relation to control plant type (Table 3, Figures 1(d)-1(e)).
3.3. Meiotic Analyses. Meiotic configurations and pollen fertility of the plant types are presented in Table 1 . The meiocytes of both control and mutant showed $2 n=14$ chromosomes always (Figures 2(a)-2(d)). Assessment of PMCs at diplotene indicated that bivalents were predominantly of rod configuration. Chiasma frequency per cell was noted to be 7.27 $\pm 0.10(7.09 \pm 0.12$ to $7.42 \pm 0.09)$ in control and $7.05 \pm 0.08$ $(6.97 \pm 0.07$ to $7.17 \pm 0.07)$ in the mutant. Bivalents formed at MI were randomly $(P>0.05$, DF 2$)$ distributed across generations in the plant types. Formation of 7II in PMCs at MI was always $100 \%$ in mutant and it varied from $80.77 \%$ to $88.46 \%$ (pooled $85.45 \%$ ) in control. Equal (7/7) segregation of chromosomes at AI was found to be $100 \%$ in the plant types (Figure $2(\mathrm{~d})$ ). However, pollen fertility was recorded to be higher in control than the mutant.

3.4. Crossings and $F_{2}$ Segregation. Out of 20 reciprocal crosses performed, only a few (4 in case-mutant as stigma parent and control as pollen parent; only 1 in opposite set) were successful in terms of fruit formation and seed setting. The hybrid capsules were smaller in size $(3.84 \mathrm{~cm}$ to $5.12 \mathrm{~cm})$ than either of the parents (control: $8.10 \mathrm{~cm} \pm 0.6$ to $8.20 \mathrm{~cm} \pm 1.2$; mutant: $7.82 \mathrm{~cm} \pm 0.28$ to $8.00 \mathrm{~cm} \pm 0.50)$ and yielded much lesser number of seeds (33 to 47 per capsule) than parents (control: $180 \pm 3.8$ to $185 \pm 2.0$ per capsule; mutant: $204 \pm 3.8$ to $210 \pm 3.54$ per capsule).

$\mathrm{F}_{1}$ plants in all sets of crossings were phenotypically similar to normal plants. $\mathrm{F}_{2}$ plants were found to segregate 


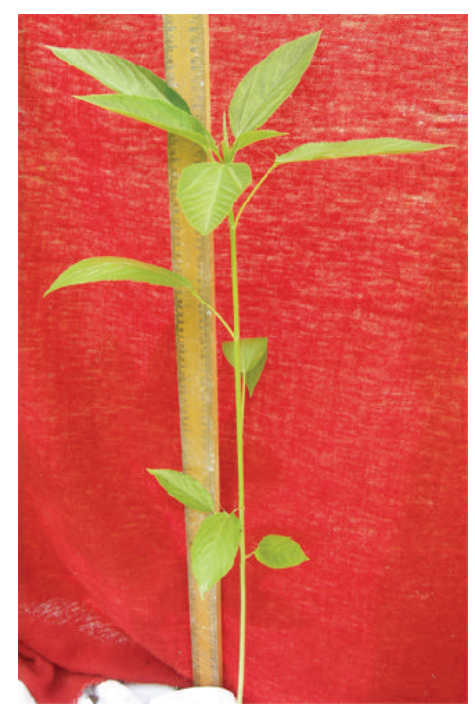

(a)

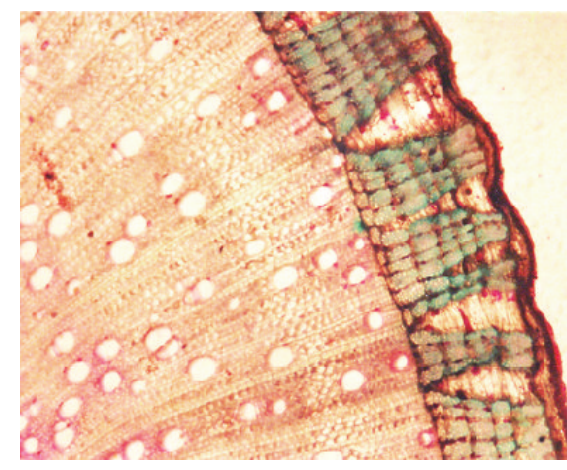

(d)

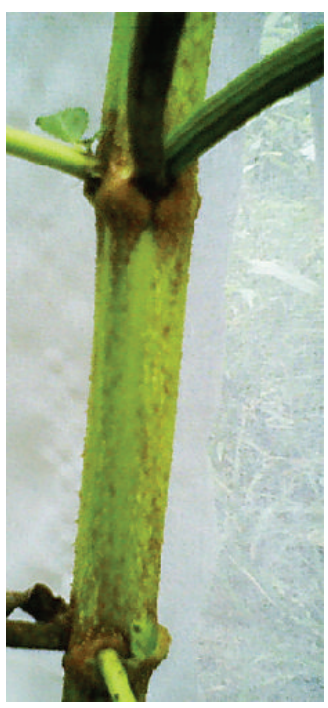

(b)

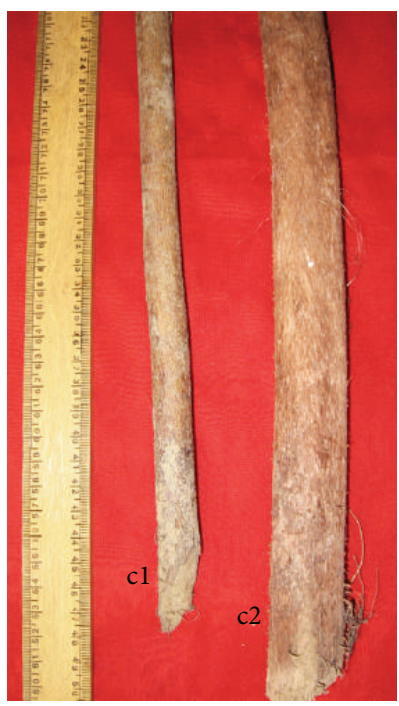

(c)

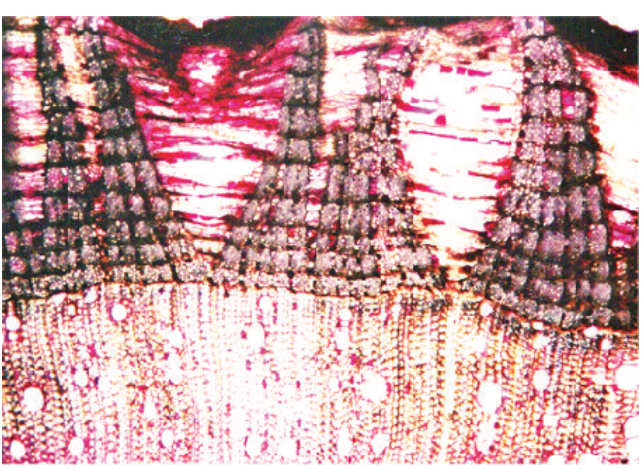

(e)

Figure 1: Tossa jute plant types ((a), (b)), sticks (c), and stem anatomy of middle zone ((d), (e)). ((a), (d)) Corchorus olitorius. ((b), (e)) "thick stem" mutant. (c) Jute sticks after retting (control: c1, mutant: c2).

into $3: 1$ (control as pollen parent $\times$ mutant as stigma parent: total 41, normal 32, mutant $09, \chi^{2}=0.20$ at $1 \mathrm{DF}, P>0.50$; reciprocal: total 29 , normal 23 , mutant $06, \chi^{2}=0.22$ at $1 \mathrm{DF}$, $P>0.60)$ ratio.

\subsection{SEM Analysis}

3.5.1. Pollen Grains. In both the plant types pollen grains were subprolate; tricolporate; medium sized (control: $42.0 \mu \mathrm{m} \pm 1.6$ $\times 36.0 \mu \mathrm{m} \pm 0.8$; mutant: $32.0 \mu \mathrm{m} \pm 1.1 \times 26.0 \mu \mathrm{m} \pm 0.7)$; colpi long (control: $33.0 \mu \mathrm{m} \pm 1.1$; mutant: $24.0 \mu \mathrm{m} \pm 0.24$ ), extending up to poles, wide, and asymmetrical; pore diameter $5.62 \mu \mathrm{m} \pm 0.3$ (control) to $5.10 \mu \mathrm{m} \pm 0.2$ (mutant); exine thick, reticulate, reticulation not uniform in size, becoming smaller towards the colpi margin; lumen area ranges from $0.22-$ $1.60 \mu \mathrm{m}^{2}$ (control) to $0.18-1.32 \mu \mathrm{m}^{2}$ (mutant), polygonal; muri $0.38 \mu \mathrm{m} \pm 0.15$ (control) to $0.30 \mu \mathrm{m} \pm 0.01$ (mutant) thick (Figures 3(a) and 3(b)).

3.5.2. Fibre. The raw jute fibre surface of both plant types following SEM are shown in (Figures 3(c) and 3(d)).
The surface of jute fibre in control was rough, multicellular, and unevenly angular with verrucose lines and covered by impurities. Fibres of "thick stem" mutant were with longitudinal ridges and furrows. Ridges were not of equal breadth, covered by impurities. Fibres of both the plant types were pitted.

3.6. Biochemical Studies. The amount of holocellulose was found to be relatively higher in mutant (94.0\% to $96.0 \%)$ than control $(88.0 \%$ to $89.0 \%)$ plant type. Lignin content in fibre was estimated to be significantly $(P<0.001$, DF 8$)$ lower in the mutant ( $4.0 \%$ to $4.5 \%)$ than control (10.5\% to $12.0 \%)$.

3.7. Physical Properties of Fibre. Fibre diameter was significantly $(t=8.614, \mathrm{DF}=48, P<0.001)$ higher in control $(0.1234 \mathrm{~mm} \pm 0.007$; range: $0.046 \mathrm{~mm}$ to $0.174 \mathrm{~mm})$ than mutant $(0.0514 \mathrm{~mm} \pm 0.005$; range: $0.026 \mathrm{~mm}$ to $0.096 \mathrm{~mm})$. Tensile strength was $27.112 \mathrm{~g} / \mathrm{tex} \pm 0.196$ in control (range: $26.40 \mathrm{~g} /$ tex to $28.10 \mathrm{~g} /$ tex) in comparison to $33.235 \mathrm{~g} / \mathrm{tex} \pm$ 0.227 in mutant (range: $32.20 \mathrm{~g} /$ tex to $34.20 \mathrm{~g} /$ tex) plant types. 


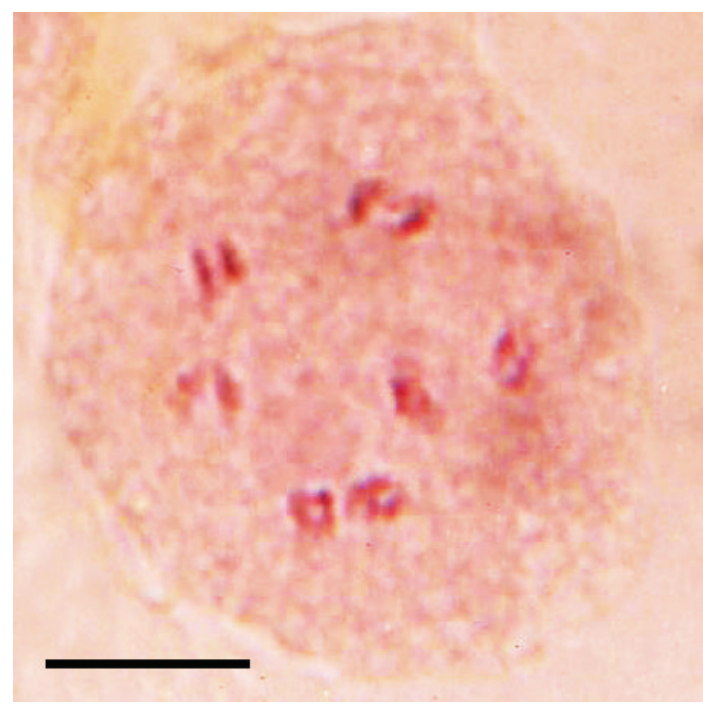

(a)

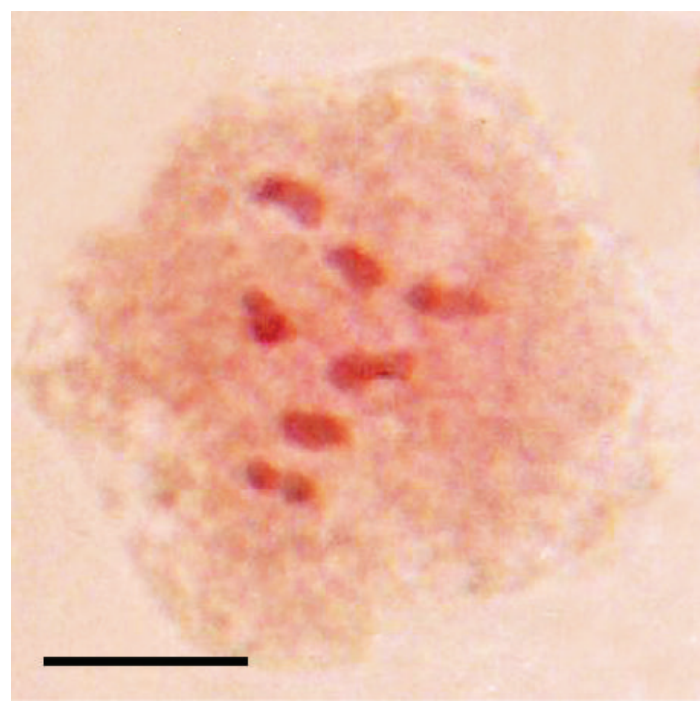

(c)

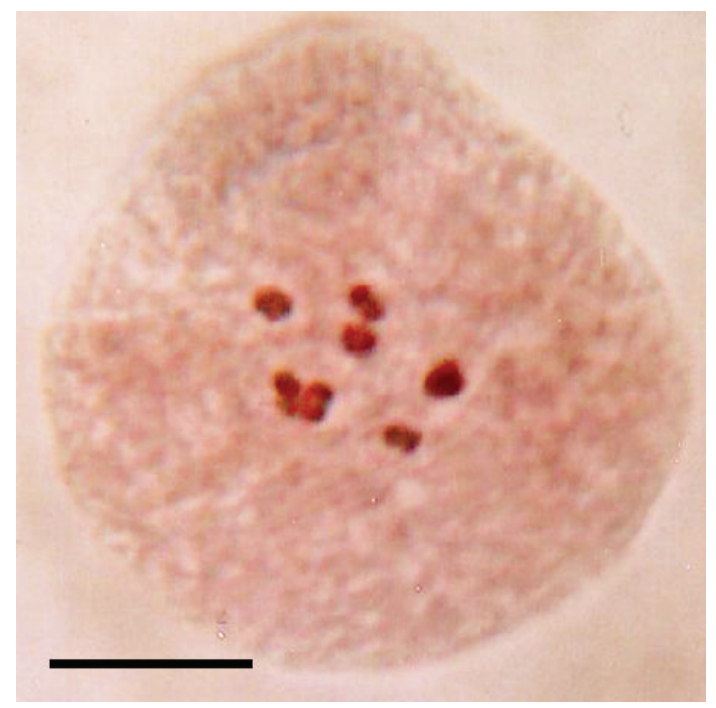

(b)

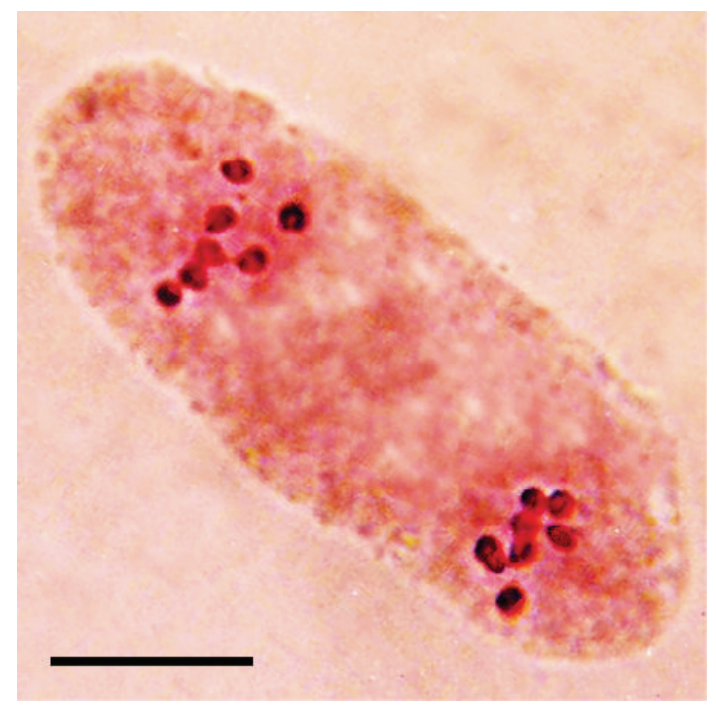

(d)

FIGURE 2: Meiotic configurations in control and mutant plant types at diplotene (a), metaphase I ((b), (c)) and anaphase I (d). ((a)-(c)) 7II. (d) 7/7 separation of chromosomes. Scale bar $=10 \mu \mathrm{m}$.

Tensile strength varied between the plant types significantly $(t=20.41, \mathrm{DF}=18, P<0.001)$.

\section{Discussion}

Results indicate that "thick stem" mutant is stable across the generations in relation to assessed parameters. The mutant resembles control in meiotic chromosome behavior but pollen fertility is rather less. The mutant trait is found monogenic recessive to normal. The "thick stem" plant type yields higher amount of seeds and fibre per plant in comparison to control. Basu [2] reported 4 high fibre yielding "thick stem" mutants in Corchorus (2 each in C. capsularis and C. olitorius) following seed treatments with X-rays and $\beta$ rays and repeated selection. The mutants were early flowering with short flowering period. "Thick stem" mutants have also been reported in other plant species [14-16]. Enhancement in biomass density in stem tissue in dicotyledonous plants resulting in thick stem is reported in Medicago truncatula and Arabidopsis thaliana to be due to disruption of stemexpressed WRKY transcription factor (TF) genes, which consequently upregulate downstream genes encoding the NAM, ATAF1/2, and CUC2 (NAC) and CCCH type (C3H) zinc finger TFs that activate secondary wall synthesis [17].

Anatomical features reveal secondary xylem activity in "thick stem" mutant along with significant enhancement in fibre zone, number of fibre pyramids and fibre bundles per pyramid, and diameter of fibre cell in relation to control. SEM analysis reveals distinct variations in raw jute fibres of control and mutant plant types; however, both are pitted and with impurities. Optical measurement of diameter of a single 


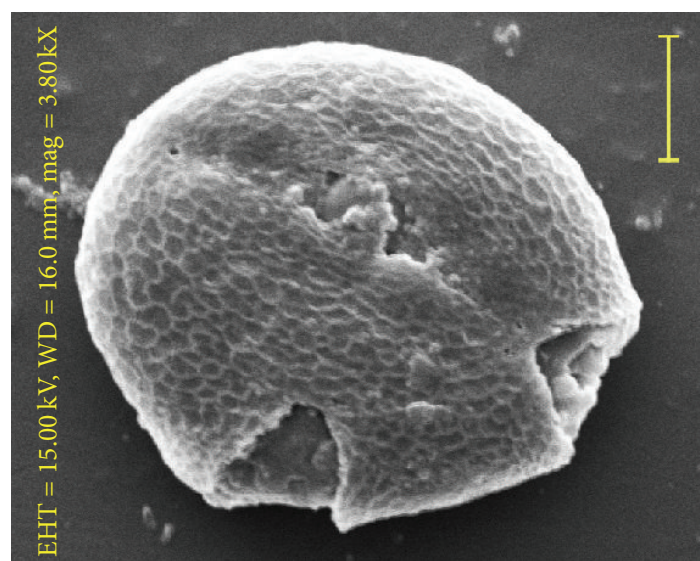

(a)

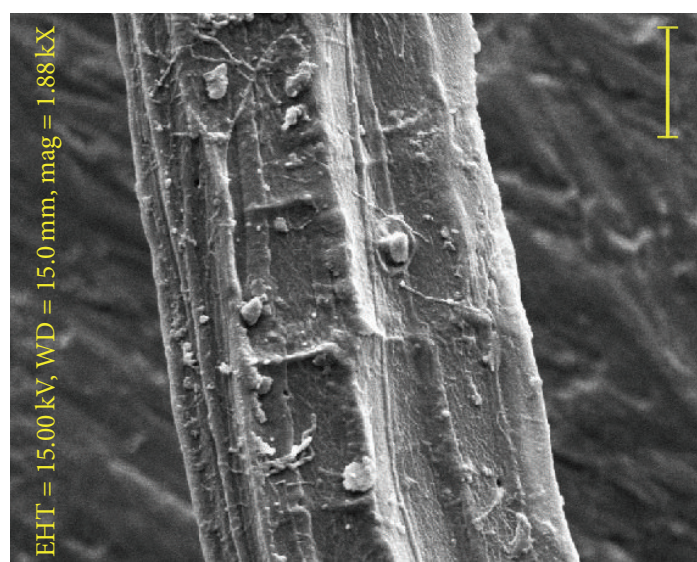

(c)

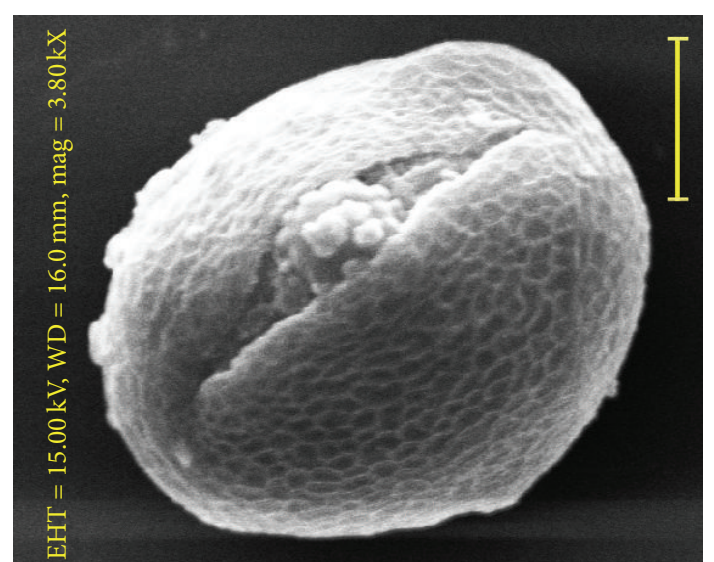

(b)

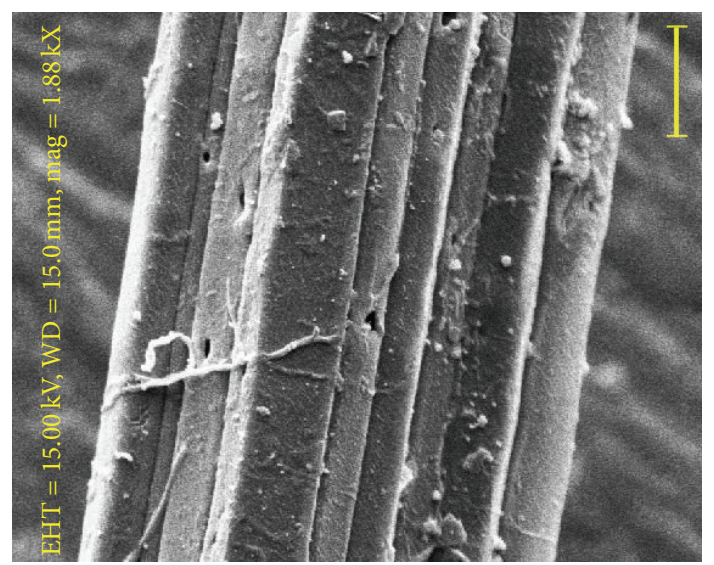

(d)

FIGURE 3: Scanning electron micrographs of pollen grains ((a), (b)) and raw jute fibres ((c), (d)). ((a) and (c)) Corchorus olitorius. ((b) and (d)) "thick stem" mutant. Scale bar $=20 \mu \mathrm{m}$.

fibre and assessment of tensile strength reveal that mutant fibres are much thinner with characteristically higher tensile strength than control fibres. Both the traits are significant for economic worth in jute $[18,19]$. Average tensile strength noted in "thick stem" mutant is much higher than the reported [20] tensile strength in C. olitorius germplasms (JRO 632-25.5 g/tex, JRO 525-26.0 g/tex, JRO 7835-26.9 g/tex, JRO 66-26.6 g/tex, JRO 872-26.1 g/tex, JRO 66-26.6 g/tex, and JRO 128-27.5 g/tex, among others). Rashed et al. [21] reported that tensile strength increases proportionally with fibre size and fibre percentage; however, after a certain size and percentage the tensile strength decreases again. Alkaline treatments are reported to enhance tensile strength in jute $[22,23]$. Inverse relationship noted between fibre diameter and tensile strength in the described mutant signifies its economic value in commerce.

The mutant also possesses low amount of lignin in retted fibres, a character of potential economic benefits. Most of the mutants and transgenic plants reported with modified lignin are xylem mutants [24-26]. Predominance of xylem mutants is possibly due to that wood is important for industrial processing, and also because tracheary elements are easier to detect than the phloem elements [27]. Furthermore, phenotypic screening for phloem mutants is reported to be rather difficult as lignin-deficient sclerenchyma cells of phloem tissue do not collapse [28] as easily as in tracheary cells [29]. Sengupta and Palit [30] reported a deficient lignified phloem fibre (dlpf) mutant in C. capsularis and the developmental deficiency has been attributed to phenylalanine lyase activity rather than peroxidase activity. Meshram and Palit [31] suggested that application of GA biosynthetic inhibitor helped to reduce lignin synthesis and to increase fibre fineness, prerequisite for fibre quality.

The mutant induced and maintained through generations possesses traits like high tensile strength and low lignin content in fibre and high fibre and seed yield per plant, which are extremely important for economic value of jute as fibre crop. However, the mutant is also associated with poor germination frequency, low seed viability, and high pollen sterility. Considering the plantation methodology adopted, germination frequency, and fibre yield per plant, it is expected that fibre yield will be about 3.18 ton/hectare in control and 2.76 ton/hectare in mutant but such variation is rather compensating due to significantly higher seed yield in mutant than control. 


\section{Conclusion}

The "thick stem" mutant is an important genetic resource in $C$. olitorius and before its commercial exploitation the undesirable traits may be eliminated through mutational approach followed by rigorous selection or through efficient breeding.

\section{Conflict of Interests}

The authors declare that there is no conflict of interests regarding the publication of this paper.

\section{Acknowledgments}

The research is grant-aided by University Grants Commission (India) and DST-PURSE Programme, Kalyani University, West Bengal, India. The authors express their sincere gratitude to Anonymous Reviewer(s) for valuable suggestions, which helped the paper to be enriched.

\section{References}

[1] M. C. Kharkwal, "Impact of mutation breeding in global agriculture," in Proceedings of the National Symposium on Plant Cytogenetics: New Approaches, p. 31, Department of Botany, Punjabi University, Patiala, India, 2012.

[2] R. K. Basu, "Induction of high-yielding mutants in jute," Mutation Research-Fundamental and Molecular Mechanisms of Mutagenesis, vol. 4, no. 2, pp. 163-167, 1967.

[3] D. P. Singh, B. K. Sharma, and S. C. Banerjee, "X-ray induced mutations in jute (C. capsularis and C. olitorius)," Genetica Agraria, vol. 27, no. 2-3, pp. 115-147, 1973.

[4] S. Chattopadhyay, S. K. Chaudhury, D. Gupta et al., "Crop improvement," in Fifty Years of Research, pp. 40-63, CRIJAF, Barrackpore, India, 1999.

[5] S. K. Chowdhury, D. Kumar, and A. Saha, "Varietal development and improved varieties of jute," in Technical Bulletin Series, vol. 1, pp. 1-12, CRIJAF Publication, 2004.

[6] S. Maity and A. K. Datta, "Induced viable macromutants in Corchorus olitorius L.", Journal of Phytological Research, vol. 22, no. 1, pp. 43-46, 2009.

[7] V. N. Patil and M. Dadlani, "Tetrazolium test for seed viability and vigour," in Handbook of Seed Testing, pp. 209-241, 2009.

[8] D. A. Johansen, "Botanical microtechnique part 2. Staining botanical section," in Plant Microtechnique, McGraw Hill, New York, NY, USA, 1940.

[9] G. E. MARKS, "An aceto-carmine glycerol jelly for use in pollen-fertility counts," Stain Technology, vol. 29, no. 5, p. 277, 1954.

[10] G. Erdtman, Pollen Morphology and Plant TaxonomyAngiosperms, Almquist and Wiksell, 1952.

[11] A. B. Sengupta, S. K. Mazumdar, and N. G. Macmillan, "Isolation of jute holocellulose by the action of sodium chlorite," Indian Journal of Applied Chemistry, vol. 21, pp. 105-110, 1958.

[12] I. M. de Rosa, J. M. Kenny, D. Puglia, C. Santulli, and F. Sarasini, "Morphological, thermal and mechanical characterization of okra (Abelmoschus esculentus) fibres as potential reinforcement in polymer composites," Composites Science and Technology, vol. 70, no. 1, pp. 116-122, 2010.
[13] S. B. Bandyopadhyay and S. K. Mukhopadhyay, "Assessment of jute fibre bundle strength," Jute Bulletin, vol. 27, pp. 193-202, 1964.

[14] R. Paul and A. K. Datta, "Gamma-rays and EMS induced macromutants in celery (Apium graveolens L.), fennel (Foeniculum vulgare Mill.) and ajowan (Trachyospermum amni L.)," Journal of Phytological Research, vol. 18, no. 1, pp. 95-98, 2005.

[15] P. K. Dubey and A. K. Datta, "Induced mutagenesis in Abelmoschus moschatus (L.) Medik," International Research Journal of Pharmacy, vol. 3, no. 5, pp. 432-435, 2012.

[16] S. Chowdhury and A. K. Datta, "Radiation induced macromutation in sesame (Sesamum indicum L.)," Journal of Phytological Research, vol. 21, no. 2, pp. 181-185, 2008.

[17] H. Wang, U. Avci, J. Nakashima, M. G. Hahn, F. Chen, and R. A. Dixon, "Mutation of WRKY transcription factors initiates pith secondary wall formation and increases stem biomass in dicotyledonous plants," Proceedings of the National Academy of Sciences of the United States of America, vol. 107, no. 51, pp. 22338-22343, 2010.

[18] A. B. Bevitori, I. L. A. da Silva, F. P. D. Lopes, and S. N. Monteiro, "Diameter dependence of tensile strength by weibull analysis: part II jute fiber," Revista Materia, vol. 15, no. 2, pp. 125-131, 2010.

[19] M. E. A. Fidelis, T. V. C. Pereira, O. D. F. M. Gomes, F. D. A. Silva, and R. D. T. Filho, "The effect of fiber morphology on the tensile strength of natural fibers," Journal of Materials Research and Technology, vol. 2, no. 2, pp. 149-157, 2013.

[20] K. C. Jain, "Fibre quality requirements for diversified uses of jute," in Book of Papers and Proceedings, Seminar on Diversified Uses of Jute \& Allied Fibre Crops, CRIJAF, Kolkata, India, 2004.

[21] H. M. M. A. Rashed, M. A. Islam, and F. B. Rizvi, "Effects of process parameters on tensile strength of jute fiber reinforced thermoplastic composites," Journal of Naval Architecture and Marine Engineering, vol. 3, no. 1, pp. 1-6, 2006.

[22] P. Saha, S. Manna, S. R. Chowdhury, R. Sen, D. Roy, and B. Adhikari, "Enhancement of tensile strength of lignocellulosic jute fibers by alkali-steam treatment," Bioresource Technology, vol. 101, no. 9, pp. 3182-3187, 2010.

[23] A. Roy, S. Chakraborty, S. P. Kundu, R. K. Basak, S. Basu Majumder, and B. Adhikari, "Improvement in mechanical properties of jute fibres through mild alkali treatment as demonstrated by utilisation of the Weibull distribution model," Bioresource Technology, vol. 107, pp. 222-228, 2012.

[24] Y. Barriere and O. Argillier, "Brown-midrib genes of maize: a review," Agronomie, vol. 13, no. 10, pp. 865-876, 1993.

[25] J. Ralph, J. J. MacKay, R. D. Hatfield, D. M. O’Malley, R. W. Whetten, and R. R. Sederoff, "Abnormal lignin in a loblolly pine mutant," Science, vol. 277, no. 5323, pp. 235-239, 1997.

[26] R. Zhong, A. Ripperger, and Z.-H. Ye, "Ectopic deposition of lignin in the pith of stems of two Arabidopsis mutants," Plant Physiology, vol. 123, no. 1, pp. 59-70, 2000.

[27] R. Aloni, "Vascular differentiation within the plant," in Vascular Differentiation and Plant Growth Regulators, L. W. Roberts, P. B. Gahan, and R. Aloni, Eds., pp. 39-62, Springer, Berlin, Germany, 1988.

[28] P. Palit, G. Sengupta, P. Datta, and J. Meshram, "Lignin and lignification with special reference to its down regulation for the improvement of wood and bast fibre quality," Indian Journal of Plant Physiology, vol. 6, no. 3, pp. 217-228, 2001.

[29] C. C. Smart and N. Amrhein, "The influence of lignification on the development of vascular tissue in Vigna radiata L," Protoplasma, vol. 124, no. 1-2, pp. 87-95, 1985. 
[30] G. Sengupta and P. Palit, "Characterization of a lignified secondary phloem fibre-deficient mutant of jute (Corchorus capsularis)," Annals of Botany, vol. 93, no. 2, pp. 211-220, 2004.

[31] J. H. Meshram and P. Palit, "On the role of cell wall lignin in determining the fineness of jute fibre," Acta Physiologiae Plantarum, vol. 35, no. 5, pp. 1565-1578, 2013. 

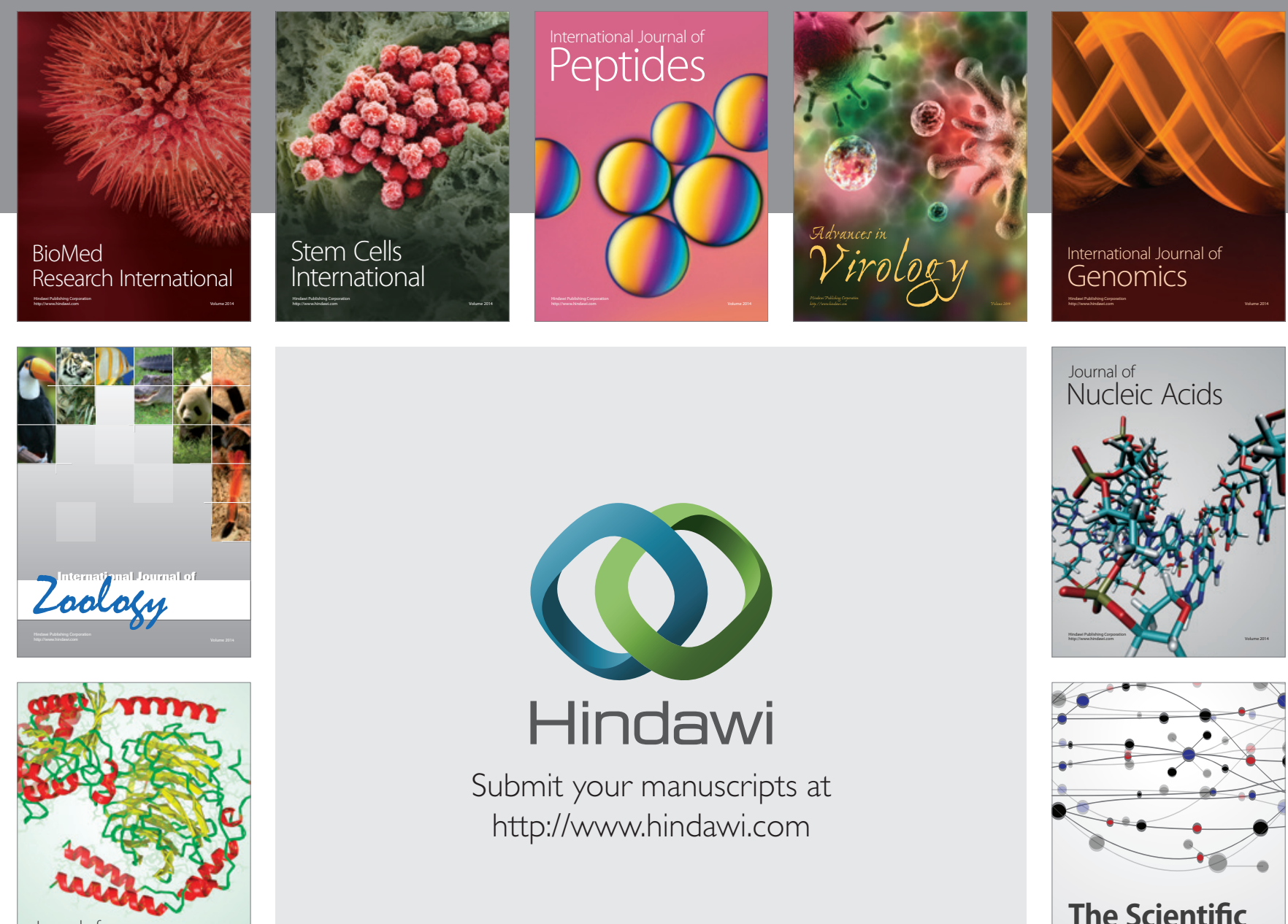

Submit your manuscripts at

http://www.hindawi.com

Journal of
Signal Transduction
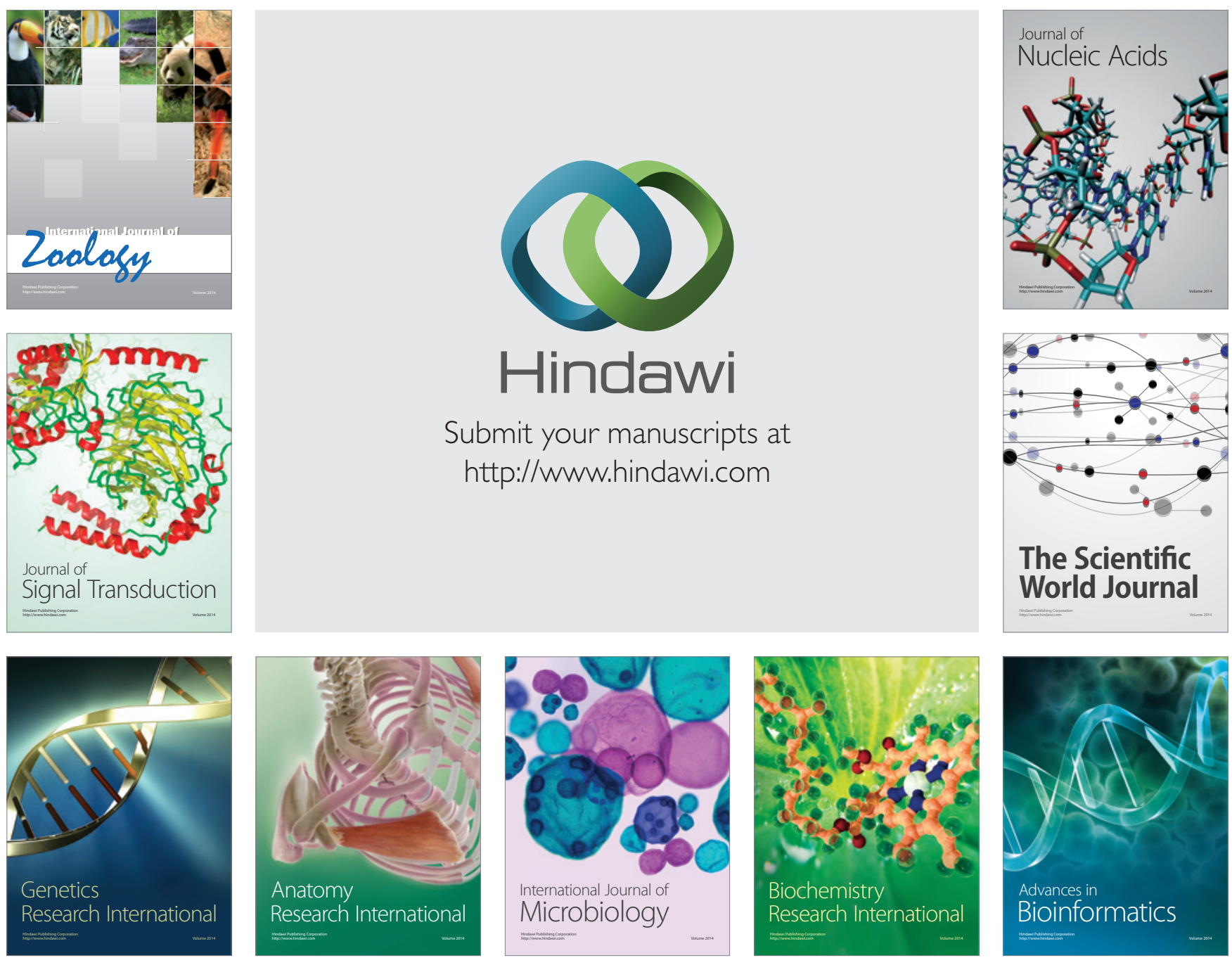

The Scientific World Journal
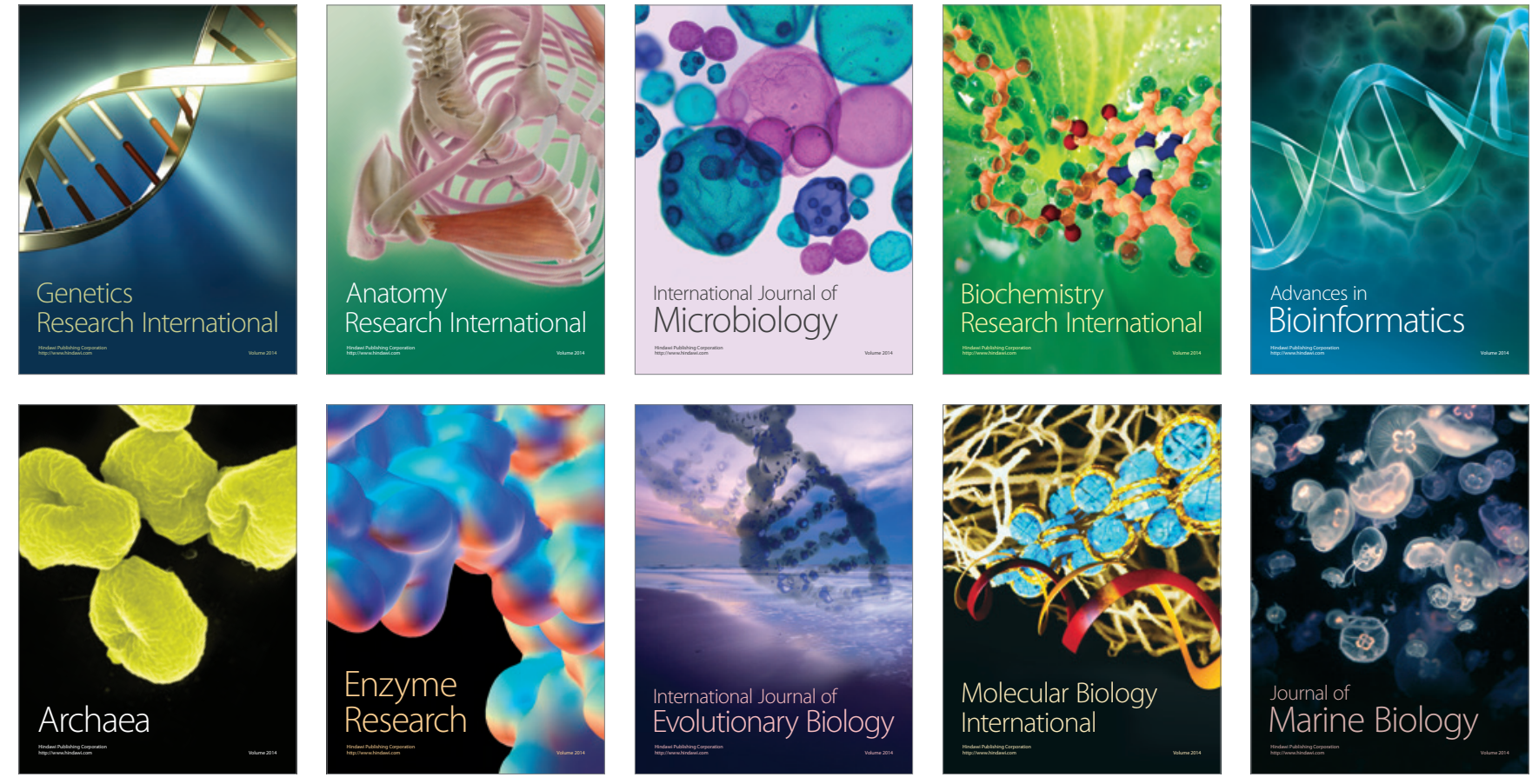